\title{
Comparison of cephalometric norms between Mongolian and Korean adults with normal occlusions and well-balanced profiles
}

\author{
Ji-Hwan Kim, DDS, MSD, ${ }^{\text {a }}$ Odontuya Gansukh, DDS, MSD, ${ }^{\text {a }}$ Bazar Amarsaikhan, DDS, PhD, \\ Shin-Jae Lee, DDS, MSD, PhD, ${ }^{\mathrm{c}}$ Tae-Woo Kim, DDS, MSD, PhD
}

\begin{abstract}
Objective: The purposes of this study were to establish cephalometric norms of Mongolian adults, which have not previously been reported in orthodontic journals, and to compare them with cephalometric norms of Korean adults. Methods: Lateral cephalometric radiographs of 74 Mongolian adults (35 men, 39 women) and 95 Korean adults (52 men, 43 women) with normal occlusions and well-balanced lateral profiles were obtained. The subjects were chosen by orthodontists of the same ethnic background. Forty craniofacial variables were measured, and groups were compared by analysis of covariance. Results: The cephalometric norms for male and female Mongolian and Korean adults with normal occlusions and well-balanced lateral profiles were established. Sexual dimorphism was found in linear skeletal measurements and vertical skeletal relationships. Compared with Korean adults, Mongolian adults had shorter anterior facial height, more prominent chins, and more upright upper incisors. There were few differences in soft tissue measurements. The differences were statistically significant, but their clinical importance may be limited. Conclusions: Cephalometric differences can be considered, but little difference may exist in the orthodontic diagnosis and treatment planning of Mongolian and Korean adults. (Korean J Orthod 2011;41(1):42-50)
\end{abstract}

Key words: Cephalometrics, Ethnic norms

\footnotetext{
${ }^{a}$ Graduate Student, ${ }^{\circ}$ Associate Professor, ${ }^{d}$ Professor, Department of Orthodontics, School of Dentistry and Dental Research Institute, Seoul National University, Seoul, Korea.

${ }^{b}$ Professor, Department of Prosthodontics and Orthodontics, School of Dentistry, Health Science University of Mongolia, Ulaanbaatar, Mongolia.

Corresponding author: Tae-Woo Kim.

Department of Orthodontics, School of Dentistry and Dental Research Institute, Seoul National University, 275-1 Yeongeondong, Jongno-gu, Seoul 110-768, Korea.

+82 22072 3317; e-mail, taewoo@snu.ac.kr.

Received August 4, 2010; Last Revision November 29, 2010 ;

Accepted December 3, 2010.

DOl:10.4041/kjod.2011.41.1.42

*This study was supported by grant No. 04-2008-0022 from the Seoul National University Dental Hospital Research Fund. We would like to thank Dr. Nomingerel Sukhbaatar, Dr. Su-Jung Ma, Dr. Yun-Sik Lee, and other staff for their assistance in data acquisition and analysis.
}

\section{INTRODUCTION}

Facial esthetics and functional occlusion have been recognized as the most important goals of orthodontic treatment. To accomplish these goals, it is important to know the normal craniofacial structure of adults in various ethnic groups.

Radiographic cephalometry is one of the most important tools of clinical and research orthodontics, and cephalometric standard values have provided useful guidelines in orthodontic diagnosis and treatment planning. However, most classical cephalometric stand$\operatorname{ards}^{1-4}$ were based on Caucasians with European ancestry, and cephalometric norms for patients from different racial and ethnic backgrounds were established later. $^{5-13}$ Korean cephalometric norms have been reported by several Korean authors ${ }^{14-17}$ and the Korean Association of Orthodontists. ${ }^{18}$ Most of these studies 
concluded that cephalometric norms are specific to an ethnic or racial group and cannot always be applied to other ethnic types.

Social and academic interest in orthodontics is increasing in Mongolia, but there are no data available in orthodontic or other professional journals concerning cephalometric standards for the Mongolian population. Various anthropological studies have reported linguistic $^{19}$ and genetic ${ }^{20-24}$ associations between Mongolians and Koreans, but cephalometric comparisons between the two related ethnic groups have not been reported.

The purposes of this study were (1) to establish the cephalometric norms of men and women adults from Mongolia who were selected on the basis of having normal occlusions and well-balanced profiles, and (2) to compare them with the cephalometric norms of the Korean samples selected with the same process. An understanding of the underlying possible structural similarities and differences between these two ethnic groups could be applied to the orthodontic diagnosis, treatment planning, and treatment mechanics.

\section{MATERIAL AND METHODS}

\section{Sample selection}

Institutional review board approval (No. CRI0927) was obtained from the Research Ethics Committee of the Clinical Dental Research Institute, Seoul National University Dental Hospital.

Selection of subjects was performed in three steps in Ulaanbaatar, Mongolia and Seoul, Korea. First, a clinical examination was performed by several orthodontists to evaluate the occlusion. Among non-growing adults of Mongolian/Korean ancestry (18 - 28 years old), subjects who were judged to have a normal occlusion were selected. Study casts and lateral cephalograms of these subjects were obtained.

For the second step, two examiners (J-H K and T-W $\mathrm{K})$ selected subjects with normal occlusion on the basis of the study casts, using the following criteria: Class I molar and canine relationship with normal occlusal interdigitation; well-aligned maxillary and mandibular dental arches with minimal crowding or spacing $(<3$ $\mathrm{mm})$; all teeth present except third molars; normal overjet and overbite $(2-4 \mathrm{~mm})$; no previous orthodontic treatment or orthognathic surgery; no or minimal restorative or prosthodontic treatment.

Finally, two Mongolian and two Korean orthodontists selected final subjects of their own ethnicity, who were judged to have well-balanced profiles with good facial harmony, based on untraced lateral cephalograms. Subjects with protrusive or retrusive profiles (upper/lower lip to Ricketts' E-line $>3 \mathrm{~mm}$ or $<-3$ $\mathrm{mm})$ were excluded.

The Mongolian subjects (35 men and 39 women) were chosen from Ulaanbaatar university students who were born in Ulaanbaatar or its suburbs and belonged to the Khalkha Mongol group. The Korean subjects (52 men and 43 women) were chosen from dental students at Seoul National University. They were born and had lived in various cities in Korea, but all were of Korean ancestry.

\section{Data acquisition}

Lateral cephalograms were taken with two cephalostats. A Veraviewepocs digital cephalostat (J. Morita Mfg. Corp., Kyoto, Japan) at the Department of Dental Radiology, Health Science University of Mongolia (target-source distance, $150 \mathrm{~cm}$ target-film distance 15 $\mathrm{cm}, 80 \mathrm{kV} ; 9 \mathrm{~mA}$ ) was used to take cephalograms of the Mongolian sample. The magnification rate was 110.0\%. A Cranex 3+ cephalostat (Orion Corporation Soredex, Helsinki, Finland) at the Department of Orthodontics, Seoul National University Dental Hospital (target-source distance, $150 \mathrm{~cm}$ target-film distance, $20 \mathrm{~cm} ; 75 \mathrm{kV} ; 10 \mathrm{~mA}$ ) was used to take cephalograms of the Korean sample. The magnification rate was $113.3 \%$. The linear measurements of the Korean sample were converted to the generally accepted magnification rate of $110.0 \%$. All cephalograms were taken with the subjects in natural head position, teeth in centric occlusion, and lips relaxed.

Lateral cephalograms of each subject were digitized and then analyzed with V-Ceph 5.3 software (Osstem, Seoul, Korea) by a single investigator (J-H K) to eliminate inter-examiner variability. All landmarks were checked twice, adjusting radiographic density, contrast, and magnification to help identify the landmarks. Landmarks 
Table 1. Cephalometric variables measured

\begin{tabular}{|c|c|}
\hline Variables & Definition \\
\hline \multicolumn{2}{|l|}{ Cranial base } \\
\hline $\mathrm{ACB}(\mathrm{mm})$ & Anterior cranial base, distance $\mathrm{S}-\mathrm{N}$ \\
\hline $\mathrm{PCB}(\mathrm{mm})$ & Posterior cranial base, distance $\mathrm{S}-\mathrm{Ar}$ \\
\hline Saddle angle $\left({ }^{\circ}\right)$ & Angle $\mathrm{N}-\mathrm{S}-\mathrm{Ar}$ \\
\hline \multicolumn{2}{|c|}{ Vertical skeletal relationship } \\
\hline Björk sum $\left(^{\circ}\right)$ & Sum of saddle angle, articular angle, and gonial angle \\
\hline $\mathrm{PFH}(\mathrm{mm})$ & Posterior facial height, distance S-Go \\
\hline $\mathrm{AFH}(\mathrm{mm})$ & Anterior facial height, distance $\mathrm{N}-\mathrm{Me}$ \\
\hline FHR & Facial height ratio, posterior to anterior facial height ratio, $\mathrm{S}-\mathrm{Go} / \mathrm{N}-\mathrm{Me}$ \\
\hline FMA $\left(^{\circ}\right)$ & Frankfort horizontal plane to mandibular plane angle \\
\hline $\mathrm{SN}-\mathrm{MP}\left({ }^{\circ}\right)$ & SN plane to mandibular plane angle \\
\hline LAFHR & Lower anterior facial height ratio, ANS-Me/N-Me \\
\hline $\mathrm{Pp} / \mathrm{Mp}$ & Palatal plane to mandibular plane angle \\
\hline $\operatorname{PpA}\left({ }^{\circ}\right)$ & Palatal plane angle, Frankfort horizontal plane to palatal plane angle \\
\hline ODI $\left({ }^{\circ}\right)$ & Overbite depth indicator \\
\hline \multicolumn{2}{|c|}{ Horizontal skeletal relationship } \\
\hline SNA $\left({ }^{\circ}\right)$ & Angle S-N-point A \\
\hline $\mathrm{SNB}\left({ }^{\circ}\right)$ & Angle S-N-point B \\
\hline $\mathrm{ANB}\left({ }^{\circ}\right)$ & Angle point $\mathrm{A}-\mathrm{N}-$ point $\mathrm{B}$ \\
\hline APDI $\left({ }^{\circ}\right)$ & Anteroposterior dysplasia indicator \\
\hline $\mathrm{A}-\mathrm{Np}(\mathrm{mm})$ & Distance from point $\mathrm{A}$ to $\mathrm{N}$-perpendicular line \\
\hline Pog-Np (mm) & Distance from Pog to N-perpendicular line \\
\hline Body to $\mathrm{ACB}$ ratio & Mandibular body length to anterior cranial base ratio, $\mathrm{Me}-\mathrm{Go} / \mathrm{S}-\mathrm{N}$ \\
\hline Pog to NB (mm) & Distance from Pog to $\mathrm{Na}-\mathrm{B}$ line \\
\hline Wits $(\mathrm{mm})$ & Distance between perpendiculars drawn from point A and point B onto the occlusal plane \\
\hline Facial convexity $\left(^{\circ}\right)$ & Angle $\mathrm{N}-\mathrm{A}-\mathrm{Pog}$ \\
\hline \multicolumn{2}{|c|}{ Size and form of mandible } \\
\hline Eff Mn length (mm) & Distance Ar-Pog \\
\hline Ramus height (mm) & Distance $\mathrm{Ar}-\mathrm{Go}$ \\
\hline Body length (mm) & Distance $\mathrm{Me}-\mathrm{Go}$ \\
\hline Articular angle $\left(^{\circ}\right)$ & Angle $\mathrm{S}-\mathrm{Ar}-\mathrm{Go}$ \\
\hline Gonial angle $\left(^{\circ}\right)$ & Angle $\mathrm{Ar}^{-} \mathrm{Go}^{-} \mathrm{Me}$ \\
\hline \multicolumn{2}{|l|}{ Dentition } \\
\hline $\mathrm{U} 1 / \mathrm{FH}\left({ }^{\circ}\right)$ & Angle formed between upper incisor axis and Frankfort horizontal plane \\
\hline $\mathrm{U} 1 / \mathrm{SN}\left({ }^{\circ}\right)$ & Angle formed between upper incisor axis and SN plane \\
\hline FMIA $\left({ }^{\circ}\right)$ & Angle formed between lower incisor axis and Frankfort horizontal plane \\
\hline $\operatorname{IMPA}\left({ }^{\circ}\right)$ & Lower incisor-mandibular plane angle \\
\hline $\operatorname{IIA}\left({ }^{\circ}\right)$ & Interincisor angle \\
\hline $\mathrm{OJ}(\mathrm{mm})$ & Overjet \\
\hline $\mathrm{OB}(\mathrm{mm})$ & Overbite \\
\hline Occl pl to $\mathrm{SN}\left({ }^{\circ}\right)$ & Angle formed between occlusal plane and SN plane \\
\hline L1-APog（mm） & Distance from L1E to point A-Pog line \\
\hline \multicolumn{2}{|l|}{ Soft tissue } \\
\hline UL to E-line (mm) & Distance from Ls to facial esthetic line (Pn-Pog') \\
\hline LL to $\mathrm{E}$-line $(\mathrm{mm})$ & Distance from Li to facial esthetic line (Pn-Pog') \\
\hline Nasolabial angle $\left(^{\circ}\right)$ & Angle $\mathrm{Cm}^{-} \mathrm{Sn}-\mathrm{Ls}$ \\
\hline
\end{tabular}


used in the study are shown in Fig 1 and measured variables are shown in Table 1.

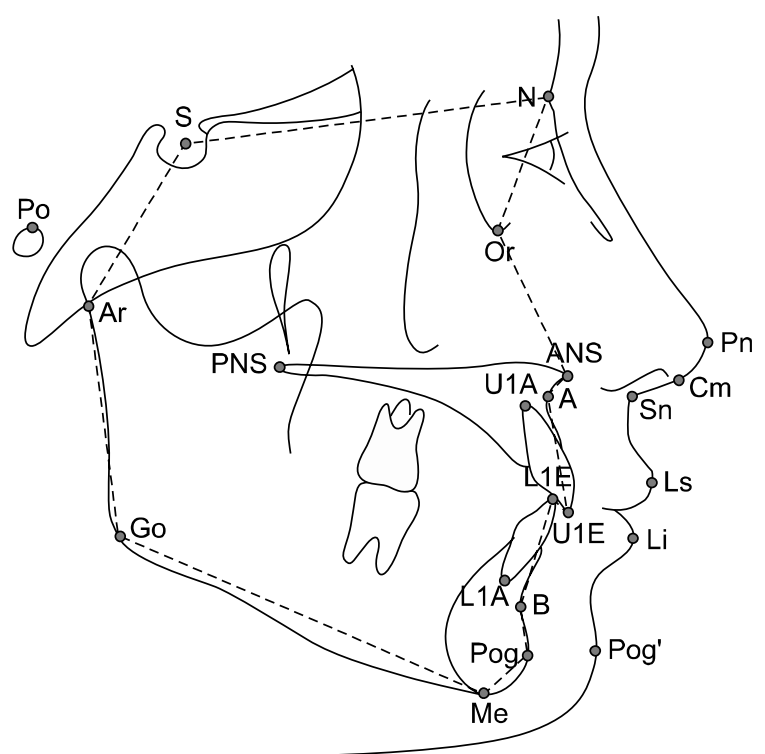

Fig 1. The cephalometric landmarks used in this study. $\mathrm{S}$, Sella; N, nasion; Or, orbitale; Po, porion; Ar, articulare; ANS, anterior nasal spine; PNS, posterior nasal spine; $A$, point $A$; $B$, point $B$; Pog, pogonion; Me, menton; Go, gonion; U1E, upper incisor edge; U1A, upper incisor root apex; L1E, lower incisor edge; L1A, lower incisor root apex; $\mathrm{Pn}$, pronasale; $\mathrm{Cm}$, columella; $\mathrm{Sn}$, subnasale; Ls, labrale superius; Li, labrale inferius; Pog', soft tissue pogonion. The broken line indicates a skeletal profile diagram with 12 representative landmarks used for comparison in Fig 2.

\section{Statistical analysis}

The reproducibility of the measurements was assessed by comparing measurements taken at least 2 weeks apart of 10 randomly selected cephalograms from each group. The selected cephalograms were redigitized by the same operator (J-H K). Dahlberg's formula $^{25}$ was used to determine the method error, which did not exceed $0.86 \mathrm{~mm}$ for the linear variables, $0.84^{\circ}$ for the angular variables, and 0.14 for the ratio variables.

Descriptive statistics were calculated for each variable, and analysis of covariance (ANCOVA) was performed to take into account age differences across the four groups (Mongolian female, Mongolian male, Korean female, Korean male) when comparing cephalometric traits between sexes and ethnic groups. Statistical significance was set at 0.05 , and the null hypotheses of this study were: cephalometric norms of males do not differ from those of females; cephalometric norms of Mongolian adults do not differ from those of Korean adults; and there is no interaction between sex and ethnicity.

\section{RESULTS}

Seventy-four Mongolian adults (35 men and 39 women) and 95 Korean adults (52 men and 43 women) were selected as subjects for this study. Age characteristics of the groups are shown in Table 2 . Mongolian subjects were significantly younger than Korean subjects.

Table 2. Age of study subjects according to sex and ethnicity

\begin{tabular}{|c|c|c|c|c|c|}
\hline \multirow[b]{2}{*}{ Age (yrs) } & \multicolumn{2}{|c|}{ Mongolian } & \multicolumn{2}{|c|}{ Korean } & \multirow[b]{2}{*}{ Multiple comparisons ${ }^{*}$} \\
\hline & $\begin{array}{c}\text { Female }(\mathrm{MF}) \\
\quad(\mathrm{n}=39)\end{array}$ & $\begin{array}{c}\text { Male (MM) } \\
\quad(\mathrm{n}=35)\end{array}$ & $\begin{array}{l}\text { Female }(\mathrm{KF}) \\
\qquad(\mathrm{n}=43)\end{array}$ & $\begin{array}{l}\text { Male }(\mathrm{KM}) \\
\quad(\mathrm{n}=52)\end{array}$ & \\
\hline Mean & 20.62 & 20.93 & 24.94 & 25.37 & \\
\hline $\mathrm{SD}$ & 2.60 & 2.33 & 2.09 & 2.30 & \\
\hline Minimum & 18.00 & 18.08 & 21.50 & 21.33 & $\mathrm{MF}=\mathrm{MM}<\mathrm{KF}=\mathrm{KM}$ \\
\hline Maximum & 27.50 & 27.50 & 28.00 & 28.00 & \\
\hline Median & 19.67 & 20.17 & 25.00 & 25.42 & \\
\hline
\end{tabular}

Min, Minimum; Max, maximum; SD, standard deviation. *Bonferroni correction for multiple comparison at the 0.05 significance level. 
Table 3. Descriptive statistics and ANCOVA of cephalometric measurements of Mongolian and Korean subjects

\begin{tabular}{|c|c|c|c|c|c|}
\hline \multirow{2}{*}{ Variables } & \multicolumn{2}{|c|}{ Mongolian } & \multicolumn{2}{|c|}{ Korean } & \multirow{2}{*}{ ANCOVA } \\
\hline & Female & Male & Female & Male & \\
\hline \multicolumn{6}{|l|}{ Cranial base } \\
\hline $\mathrm{ACB}(\mathrm{mm})$ & $71.55 \pm 2.96$ & $74.16 \pm 3.18$ & $72.02 \pm 3.33$ & $74.98 \pm 3.87$ & Male $>$ female $^{\ddagger}$ \\
\hline $\mathrm{PCB}(\mathrm{mm})$ & $37.65 \pm 2.68$ & $41.76 \pm 3.29$ & $39.99 \pm 6.70$ & $42.74 \pm 3.00$ & Male $>$ female $^{\ddagger}$ \\
\hline Saddle angle $\left(^{\circ}\right)$ & $126.97 \pm 4.48$ & $125.98 \pm 6.44$ & $123.83 \pm 4.79$ & $124.02 \pm 5.24$ & NS \\
\hline \multicolumn{6}{|c|}{ Vertical skeletal relationship } \\
\hline Björk sum $\left(^{\circ}\right)$ & $392.94 \pm 4.46$ & $389.92 \pm 4.44$ & $392.71 \pm 4.18$ & $391.50 \pm 5.18$ & Male $<$ female $^{\dagger}$ \\
\hline $\mathrm{PFH}(\mathrm{mm})$ & $85.80 \pm 6.32$ & $95.68 \pm 5.68$ & $88.11 \pm 5.59$ & $96.78 \pm 6.34$ & Male $>$ female $^{\ddagger}$ \\
\hline $\mathrm{AFH}(\mathrm{mm})$ & $128.62 \pm 4.55$ & $136.03 \pm 5.36$ & $131.00 \pm 6.62$ & $139.80 \pm 6.52$ & Male $>$ female $^{\ddagger}$, Mongolian $<$ Korean* \\
\hline FHR (\%) & $66.71 \pm 4.31$ & $70.36 \pm 3.70$ & $67.30 \pm 3.45$ & $69.30 \pm 4.51$ & Male $>$ female $^{\ddagger^{\prime}}$ \\
\hline FMA $\left(^{\circ}\right)$ & $25.00 \pm 4.21$ & $22.13 \pm 4.59$ & $23.87 \pm 4.19$ & $23.65 \pm 5.19$ & Male $<$ female $^{*}$ \\
\hline $\mathrm{SN}-\mathrm{MP}\left({ }^{\circ}\right)$ & $32.92 \pm 4.47$ & $29.90 \pm 4.58$ & $32.64 \pm 4.18$ & $31.45 \pm 5.19$ & Male $<$ female $^{\dagger}$ \\
\hline LAFHR & $0.55 \pm 0.02$ & $0.55 \pm 0.02$ & $0.54 \pm 0.02$ & $0.54 \pm 0.02$ & NS \\
\hline $\mathrm{Pp} / \mathrm{Mp}\left({ }^{\circ}\right)$ & $24.69 \pm 4.03$ & $22.35 \pm 3.78$ & $22.94 \pm 4.38$ & $21.99 \pm 5.15$ & Male $<$ female $^{*}$ \\
\hline $\operatorname{PpA}\left({ }^{\circ}\right)$ & $0.31 \pm 3.86$ & $-0.23 \pm 2.93$ & $0.88 \pm 2.70$ & $1.65 \pm 2.60$ & NS \\
\hline ODI $\left({ }^{\circ}\right)$ & $72.68 \pm 5.28$ & $74.33 \pm 4.76$ & $72.98 \pm 4.59$ & $75.13 \pm 5.13$ & Male $>$ female $^{*}$ \\
\hline \multicolumn{6}{|c|}{ Horizontal skeletal relationship } \\
\hline SNA $\left(^{\circ}\right)$ & $81.82 \pm 2.61$ & $82.54 \pm 3.46$ & $81.61 \pm 2.84$ & $82.32 \pm 3.06$ & NS \\
\hline $\mathrm{SNB}\left({ }^{\circ}\right)$ & $78.92 \pm 2.60$ & $79.73 \pm 3.26$ & $79.01 \pm 3.26$ & $79.39 \pm 2.99$ & NS \\
\hline $\mathrm{ANB}\left({ }^{\circ}\right)$ & $2.90 \pm 1.77$ & $2.81 \pm 1.57$ & $2.59 \pm 1.84$ & $2.94 \pm 1.49$ & $\mathrm{NS}$ \\
\hline $\mathrm{APDI}\left({ }^{\circ}\right)$ & $82.92 \pm 4.11$ & $83.07 \pm 3.02$ & $84.88 \pm 4.89$ & $84.47 \pm 3.72$ & Mongolian $<$ Korean $^{*}$ \\
\hline A-Np (mm) & $-0.22 \pm 3.24$ & $0.37 \pm 3.05$ & $0.55 \pm 2.64$ & $0.20 \pm 3.18$ & NS \\
\hline Pog-Np (mm) & $-4.64 \pm 5.84$ & $-3.19 \pm 6.08$ & $-3.55 \pm 6.59$ & $-4.51 \pm 6.06$ & NS \\
\hline Body to $\mathrm{ACB}$ ratio & $1.11 \pm 0.07$ & $1.11 \pm 0.06$ & $1.12 \pm 0.08$ & $1.12 \pm 0.07$ & NS \\
\hline Pog to NB (mm) & $1.91 \pm 1.30$ & $2.33 \pm 1.56$ & $1.10 \pm 1.81$ & $1.94 \pm 1.45$ & Male $>$ female $^{*}$ Mongolian $>$ Korean $^{\dagger}$ \\
\hline Wits $(\mathrm{mm})$ & $0.16 \pm 2.42$ & $1.19 \pm 2.52$ & $-1.13 \pm 6.81$ & $-0.58 \pm 2.40$ & Mongolian > Korean* \\
\hline Facial convexity $\left(^{\circ}\right)$ & $4.14 \pm 4.16$ & $3.68 \pm 4.31$ & $4.32 \pm 4.95$ & $4.34 \pm 3.56$ & NS \\
\hline \multicolumn{6}{|c|}{ Size and form of mandible } \\
\hline Eff Mn length (mm) & $114.85 \pm 4.75$ & $120.86 \pm 4.86$ & $113.34 \pm 6.82$ & $121.17 \pm 4.10$ & Male $>$ female $^{\ddagger}$ \\
\hline Ramus height (mm) & $52.17 \pm 4.80$ & $58.21 \pm 4.29$ & $50.90 \pm 7.07$ & $57.57 \pm 5.21$ & Male $>$ female $^{\ddagger}$ \\
\hline Body length (mm) & $79.56 \pm 4.83$ & $82.59 \pm 4.79$ & $80.59 \pm 5.83$ & $83.63 \pm 3.71$ & Male $>$ female $^{\ddagger}$ \\
\hline Articular angle $\left({ }^{\circ}\right)$ & $145.70 \pm 6.80$ & $146.20 \pm 5.94$ & $152.07 \pm 6.55$ & $149.92 \pm 6.55$ & Mongolian $<$ Korean $^{*}$ \\
\hline Gonial angle $\left(^{\circ}\right)$ & $120.27 \pm 6.57$ & $117.74 \pm 5.58$ & $116.80 \pm 5.89$ & $117.61 \pm 6.77$ & $\mathrm{NS}$ \\
\hline \multicolumn{6}{|l|}{ Dentition } \\
\hline $\mathrm{U} 1 / \mathrm{FH}\left(^{\circ}\right)$ & $109.33 \pm 5.72$ & $110.86 \pm 5.08$ & $112.13 \pm 5.67$ & $112.27 \pm 5.54$ & Mongolian $<$ Korean $^{\dagger}$ \\
\hline $\mathrm{U1} / \mathrm{SN}\left({ }^{\circ}\right)$ & $101.42 \pm 5.65$ & $103.08 \pm 5.09$ & $103.33 \pm 5.78$ & $104.47 \pm 5.96$ & 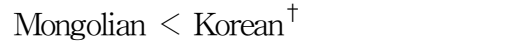 \\
\hline FMIA $\left(^{\circ}\right)$ & $59.36 \pm 6.13$ & $60.98 \pm 5.26$ & $59.22 \pm 7.07$ & $59.60 \pm 5.62$ & $\mathrm{NS}$ \\
\hline $\operatorname{IMPA}\left({ }^{\circ}\right)$ & $95.64 \pm 5.75$ & $96.89 \pm 5.17$ & $96.91 \pm 5.12$ & $96.75 \pm 6.02$ & NS \\
\hline IIA $\left(^{\circ}\right)$ & $130.03 \pm 7.26$ & $130.12 \pm 7.06$ & $127.09 \pm 7.29$ & $127.33 \pm 7.52$ & 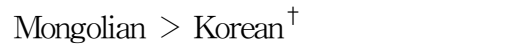 \\
\hline $\mathrm{OJ}(\mathrm{mm})$ & $3.52 \pm 0.69$ & $3.63 \pm 1.00$ & $3.05 \pm 0.92$ & $3.39 \pm 0.89$ & Mongolian > Korean* \\
\hline $\mathrm{OB}(\mathrm{mm})$ & $2.54 \pm 0.90$ & $2.11 \pm 1.17$ & $1.74 \pm 1.36$ & $1.90 \pm 1.23$ & 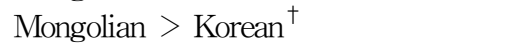 \\
\hline Occl pl to $\mathrm{SN}\left({ }^{\circ}\right)$ & $15.11 \pm 3.30$ & $12.93 \pm 3.95$ & $16.10 \pm 10.32$ & $15.72 \pm 3.98$ & $\mathrm{NS}$ \\
\hline L1-APog (mm) & $1.53 \pm 2.72$ & $1.67 \pm 2.73$ & $2.95 \pm 2.60$ & $2.14 \pm 2.50$ & Mongolian $<$ Korean $^{\dagger}$ \\
\hline \multicolumn{6}{|l|}{ Soft tissue } \\
\hline UL to E-line (mm) & $-0.8 \pm 1.63$ & $-0.83 \pm 1.64$ & $-1.66 \pm 2.28$ & $-1.16 \pm 1.90$ & NS \\
\hline LL to E-line (mm) & $-0.11 \pm 1.78$ & $-0.21 \pm 2.10$ & $-0.04 \pm 2.23$ & $-0.09 \pm 2.11$ & NS \\
\hline Nasolabial angle $\left(^{\circ}\right)$ & $93.39 \pm 9.97$ & $93.10 \pm 10.40$ & $97.63 \pm 9.25$ & $94.54 \pm 10.95$ & NS \\
\hline
\end{tabular}

Results are expressed as mean \pm standard deviation. NS, Not significant. ${ }^{*} p<0.05 ;{ }^{\dagger} p<0.01 ;{ }^{\ddagger} p<0.001$. 
Table 3 shows the cephalometric measurements of the subjects according to sex and ethnicity. Cephalometric measurements of the groups were compared by ANCOVA, using age as the covariate. Interactions between sex and ethnicity were not significant for all measurements.

Of the 40 craniofacial measurements, 14 showed significant sexual dimorphism, which primarily reflected differences in size (anterior and posterior cranial base, anterior and posterior facial height, effective mandibular length, ramus height, and mandibular body length) or vertical skeletal relationship (Björk sum, facial height ratio, Frankfort mandibular plane angle, anterior cranial base-mandibular plane angle, palatal plane to mandibular plane angle, and overbite depth indicator). Female subjects exhibited a more vertical skeletal pattern, but no differences were observed in dental or soft tissue measures (Table 3).

Comparison of the two ethnic groups showed that Mongolian subjects had shorter anterior facial height (AFH, $p<0.05)$ with decreased articular angle $(p<$ $0.05)$ and increased Pog-NB line distance $(p<0.01)$ compared with Korean subjects. In the dentition, Mongolian subjects exhibited less proclination of the upper incisors (smaller U1/FH and U1/SN angle, $p<$ $0.01)$, larger interincisal angle $(p<0.01)$, and larger overjet $(p<0.05)$ and overbite $(p<0.01)$ than

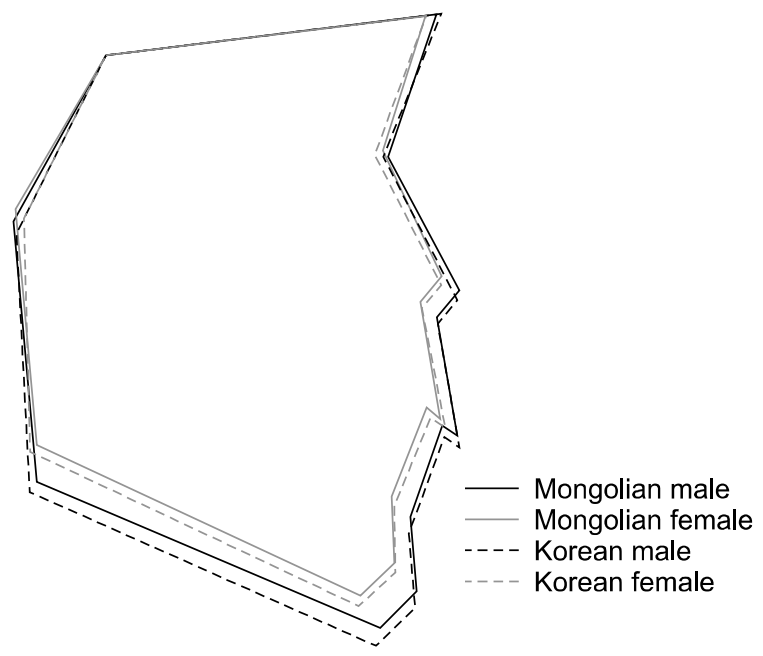

Fig 2. Comparison of skeletal profile diagrams among Mongolian male, Mongolian female, Korean male, and Korean female subjects.
Korean subjects. No differences were seen in soft tissue measurements between Mongolian and Korean subjects.

The skeletal profile diagrams were constructed according to ethnicity and sex, and superimposed images were registered on the sella point and oriented on the sella-nasion line (Fig 2).

\section{DISCUSSION}

In this study, we established cephalometric norms by evaluating untreated Mongolian and Korean subjects with normal occlusions and well-balanced lateral profiles. We chose inclusion criteria and methodology to identify normative values for diagnosis and treatment planning for Mongolian and Korean adults seeking orthodontic treatment or orthognathic surgery. Previous studies of Korean cephalometric norms ${ }^{16,18}$ focused primarily on good occlusion rather than balanced faces. With an increasing awareness of esthetic dentistry, a norm based on esthetically pleasing faces would be useful. On the other hand, skeletal variations may exist in subjects with a Class I molar relationship. ${ }^{26,27}$ For this reason, the present study included a subsample of subjects who were judged to have well-balanced profiles.

Reducing selection bias is important when establishing population norms. For this study, untreated university students were selected to obtain a representative sample of normal Mongolian and Korean non-growing adults, whereas other studies ${ }^{5,13}$ used records of individuals who sought orthodontic treatment, which risks introducing selection bias. Sample selection used primarily objective criteria such as Angle classification, proper overbite and overjet, lack of crowding, spacing, and excessive restoration. Orthodontists from each ethnic background examined the facial profile, which was the only subjective criterion, and the subjects were selected by consensus of the examiners. Positions of the upper and lower lip relative to Ricketts' E-line were evaluated to support the selection criteria.

Among ethnic comparison studies, some studies ${ }^{7,9,17}$ analyzed more than one ethnic group at a time, but many others measured only one ethnic group and compared the measurements with norms of other published 
studies, which may cause problems due to differences in sample selection, landmark definition, and potential inter-observer error. In this study, we obtained data from both the Mongolian and Korean subjects, and one investigator digitized both groups of cephalograms simultaneously to reduce selection and measurement biases.

Ethnic homogeneity was achieved by selecting the sample of Korean/Mongolian ancestry. The Ethnic Homogeneity Index ${ }^{1)}$ for Korea and Mongolia has been reported to be 1.00 and 0.69 , respectively, ${ }^{28}$ reflecting a high degree of homogeneity. The Korean population shares facial features that are distinct, even from those of other Asian groups. The Korean subjects in this study originated from different cities in Korea, but all were of Korean ancestry. The Mongolian population can be divided into four groups; the Khalkha Mongols make up the majority of modern Mongolians. ${ }^{21}$ All Mongolian subjects in this study had Khalkha Mongol family names.

The cephalometric measurement data were separated according to sex and ethnicity to obtain specific and useful cephalometric normative values. Because of the significant difference in the mean age among the groups, ANCOVA was performed using age as the covariable.

Sexual dimorphism was found to be significant, especially for skeletal linear measurements and vertical skeletal relationships (Table 3). Along with the expected differences in skeletal linear measurements, women showed more vertical patterns in most vertical angular measurements. Among intergender comparisons in other ethnic studies, some ${ }^{7,12}$ reported no significant differences between men and women; however, Miyajima et al. ${ }^{9}$ reported that Japanese women had more vertically oriented facial axis angles and mandibular plane angles, which is consistent with our results.

In the present study, no statistically significant sexual dimorphism was detected in dental and soft tissue measurements. This result supports the findings of Miyajima et al. ${ }^{9}$ and Basciftci et al., ${ }^{10}$ who did not find dental or soft tissue sexual dimorphisms in Japanese and Anatolian Turkish adults. However, in the sophisti-

1) Ethnic Homogeneity Index $=\sum$ (fraction of ethnic group $)^{2}$ cated soft tissue measurements by Hwang et al., ${ }^{17}$ Korean subjects showed sexual dimorphism in the nose, lower lip, and mentolabial sulcus area. We performed only three soft tissue measurements in our study, which may explain, at least in part, why no differences were found.

Our results showed that cranial base length of the Mongolian subjects was similar to that of the Korean subjects, but the AFH was shorter in the Mongolian subjects. The mean differences in AFH were $3.77 \mathrm{~mm}$ in men and $2.38 \mathrm{~mm}$ in women, which was the most obvious difference between the two ethnic groups. Most variables reflecting mandible size did not differ significantly, but the chin was more prominent in Mongolian subjects. The Wits appraisal value, which is affected by the cant of occlusal plane, ${ }^{29}$ was larger in Mongolian subjects. Along with genetic factors, various environmental factors like mastication stress can influence the occlusal plane as well as facial types and growth patterns, ${ }^{30}$ but the clinical significance of these differences may not be great.

Previous studies that compared cephalometric features of Caucasian populations with Asians ${ }^{8,9,16}$ or with African Americans ${ }^{11}$ reported the greatest racial differences in the soft tissue profile and dentoalveolar protrusion, concluding that the convexity and the interincisal angle are characteristic of each race. Few studies have compared two or more ethnic groups of the same race. Despite differences in sample selection criteria and measurements, multicenter studies by Trenouth et al. $^{31}$ and el-Batouti et al. ${ }^{5}$ demonstrated that differences exist within Caucasian populations. In this study, which compared the cephalometric features between two Asian ethnic groups, soft tissue measurements did not differ significantly between the two ethnic groups, but differences in dentition variables were observed. Upper incisors were more proclined in Korean subjects, which may affect the interincisal angle. However, the mean differences in the U1/SN angle $\left(1.39^{\circ}\right.$ in men and $1.91^{\circ}$ in women) were smaller, with limited clinical significance, compared with differences reported by studies comparing Asian and Caucasian populations. ${ }^{9,16,32}$ The mandibular incisor plane angle was similar in both groups, but the L1APog distance was smaller in Mongolian subjects, who 
have more prominent chins, as reflected by the Pog to NB variable.

The observed differences between the two groups in this study may reflect differences in the populations from which they were drawn. Although all subjects were Asian, it is possible that there were ethnic differences, as there are two recognized subgroups, North Asians and South Asians. It is possible that the populations of Mongolia and Korea differ in the proportion of these two subgroups, which could therefore account for the observed morphologic differences. Studies $^{20,21}$ of genetic markers showed that Koreans tend to have a close genetic affinity with Mongolians among East Asians. However, more recent surveys ${ }^{22-24}$ of Y-chromosomal DNA variation have revealed that the Korean population contains lineages typical of both southern and northern East Asian populations.

The perception of facial esthetics differs by culture, individuals within the culture, and with time. ${ }^{33}$ In a study by Ko et al., ${ }^{34}$ the same ethnic groups with different cultural background showed statistically different preferences when judging esthetic profiles. Therefore, our sample selection procedure may have influenced the results. Despite the possible ethnic differences, the small differences between the two groups suggest that these results should be interpreted carefully.

The results of this study have clinical implications for the diagnosis and treatment planning of adult Mongolian patients. Features of Mongolian adults were very similar to those of Korean adults. Significant differences were detected only in relation to vertical facial height, chin prominence, and inclination of upper incisors. However, the clinical importance of these differences may be limited regarding the diagnosis and treatment planning of Mongolian and Korean adults.

\section{CONCLUSION}

In the present study, we established cephalometric norms for male and female Mongolian adults with normal occlusions and well-balanced lateral profiles. Sexual dimorphism was found in skeletal linear measurements and vertical skeletal relationships. Mongolian adults had shorter AFH, more prominent chins, and more upright upper incisors than Korean adults, but few differences were observed in the soft tissue measurements. Because of limited clinical significance in differences between the two ethnic groups, similar diagnosis and treatment planning are feasible for Mongolian and Korean patients seeking orthodontic treatment or orthognathic surgery.

- 국문초록 -

조화로운 측모를 가진 몽골인과 한국인 성인 정상교합자의 측모두부계측방사선학적 비교 연구

$$
\begin{gathered}
\text { 김지환 - Odontuya Gansukh - Bazar Amarsaikhan } \\
\text { 이신재 · 김태우 }
\end{gathered}
$$

현재까지 몽골인의 측모두부계측방사선학적 기준치가 문 헌 상으로 보고된 바가 없었던 바, 본 연구의 목적은 정상교 합과 조화로운 측모를 가진 몽골인을 선별하여 측모두부계 측방사선학적 기준치를 제시하고, 이를 같은 기준으로 선별 한 한국인의 기준치와 비교하는 것이다. 조화로운 측모를 가 진 74 명의 몽골인(남자 35 명, 여자 39 명)과 95 명의 한국인 (남자 52명, 여자 43명) 성인 정상교합자들의 측모두부계측 방사선 사진을 채득하였다. 이들은 해당 민족과 국적의 교정 의사들의 평가로 선별되었다. 40 개의 계측치에 대하여 민족 별, 성별 평균 및 표준편차를 산출한 후, 그 차이를 ananlysis of covariance (ANCOVA)로 검정하였다. 조화로운 측모 를 가진 몽골인과 한국인 남녀 성인 정상교합자의 측모두부 방사선학적 기준치를 얻었다. 골격성 선 계측치와 수직적 골 격 관계에서 성별 간의 유의한 차이가 나타났다. 몽골인은 한국인에 비하여 짧은 전안면 고경, 돌출된 이부, 설측경사 된 상악 전치를 나타내었으나, 대부분의 계측치 간 평균 차 이가 적어 임상적 의미는 적었다. 몽골인과 한국인 성인 환 자의 교정치료를 위한 진단과 치료계획 시에 유사한 기준을 적용할 수 있을 것이라고 생각되었다.

주요 단어: 측모두부계측방사선학, 인종별 기준치

\section{REFERENCES}

1. Downs WB. Variations in facial relationships; their significance in treatment and prognosis. Am J Orthod 1948;34: 812-40.

2. Steiner CC. Cephalometrics for you and me. Am J Orthod 1953;39:729-55.

3. Tweed $\mathrm{CH}$. The Frankfort-mandibular incisor angle (FMIA) in 
orthodontic diagnosis, treatment planning and prognosis. Angle Orthod 1954;24:121-69.

4. Ricketts RM. Planning treatment on the basis of the facial patterns and an estimate of its growth. Angle Orthod 1957;27: 14-37.

5. el-Batouti A, Ogaard B, Bishara SE. Longitudinal cephalometric standards for Norwegians between the ages of 6 and 18 years. Eur J Orthod 1994;16:501-9.

6. Cotton WN, Takano WS, Wong WM. The Downs analysis applied to three other ethnic groups. Angle Orthod 1951;21: 213-20.

7. Cooke MS, Wei SH. A comparative study of southern Chinese and British Caucasian cephalometric standards. Angle Orthod 1989;59:131-8.

8. Wu J, Hägg U, Rabie AB. Chinese norms of McNamara's cephalometric analysis. Angle Orthod 2007;77:12-20.

9. Miyajima K, McNamara JA Jr, Kimura T, Murata S, lizuka T. Craniofacial structure of Japanese and European-American adults with normal occlusions and well-balanced faces. Am J Orthod Dentofacial Orthop 1996;110:431-8.

10. Basciftci FA, Uysal T, Buyukerkmen A. Craniofacial structure of Anatolian Turkish adults with normal occlusions and well-balanced faces. Am J Orthod Dentofacial Orthop 2004; 125:366-72.

11. Huang WJ, Taylor RW, Dasanayake AP. Determining cephalometric norms for Caucasians and African Americans in Birmingham. Angle Orthod 1998;68:503-11.

12. Hamdan AM, Rock WP. Cephalometric norms in an Arabic population. J Orthod 2001;28:297-300.

13. Yeong P, Huggare J. Morphology of Singapore chinese. Eur J Orthod 2004;26:605-12.

14. Yang WS. A roentgenocephalometric study of the linear analyses in normal occlusion for Korean. Korean J Orthod 1974; 4:7-12.

15. Lee KS, Chung KR. A cephalometric analysis of Korean adult normal occlusion. Korean J Orthod 1987;17:199-214.

16. Park IC, Bowman D, Klapper L. A cephalometric study of Korean adults. Am J Orthod Dentofacial Orthop 1989;96:54-9.

17. Hwang HS, Kim WS, McNamara JA Jr. Ethnic differences in the soft tissue profile of Korean and European-American adults with normal occlusions and well-balanced faces. Angle Orthod 2002;72:72-80

18. Malocclusion Report Publication Committee of KAO. The report of cephalometric measurement study of Korean adults with normal occlusion. 1997. p. 1-17.

19. Georg S, Michalove PA, Ramer AM, Sidwell PJ. Telling general linguists about Altaic. J Linguistics 1999;35:65-98.
20. Saha N, Tay JS. Origin of the Koreans: a population genetic study. Am J Phys Anthropol 1992;88:27-36.

21. Chimge NO, Batsuuri J. Interethnic genetic differentiation: HLA class I antigens in the population of Mongolia. Am J Hum Biol 1999;11:603-18.

22. Kim W, Shin DJ, Harihara S, Kim YJ. Y chromosomal DNA variation in east Asian populations and its potential for inferring the peopling of Korea. J Hum Genet 2000;45:76-83.

23. Karafet T, Xu L, Du R, Wang W, Feng S, Wells RS, et al. Paternal population history of East Asia: sources, patterns, and microevolutionary processes. Am J Hum Genet 2001;69: 615-28.

24. Jin HJ, Kwak KD, Hammer MF, Nakahori Y, Shinka T, Lee $\mathrm{JW}$, et al. Y-chromosomal DNA haplogroups and their implications for the dual origins of the Koreans. Hum Genet 2003; 114:27-35.

25. Dahlberg G. Statistical methods for medical and biological students. London: George Allen and Unwin Ltd.; 1940.

26. Casko JS, Shepherd WB. Dental and skeletal variation within the range of normal. Angle Orthod 1984;54:5-17.

27. Kim JY, Lee SJ, Kim TW, Nahm DS, Chang YI. Classification of the skeletal variation in normal occlusion. Angle Orthod 2005;75:311-9.

28. Goldstone JA, Gurr TA, Harff B, Levy MA, Marshall MG, Bates RH, et al. State Failure Task Force Report: Phase III Findings. McLean, VA: Science Applications International Corporation 2000. (Available at: http://globalpolicy.gmu.edu/ pitf/. Accessed June 21, 2010)

29. Del Santo M Jr. Influence of occlusal plane inclination on ANB and Wits assessments of anteroposterior jaw relationships. Am J Orthod Dentofacial Orthop 2006;129:641-8.

30. King L, Harris EF, Tolley EA. Heritability of cephalometric and occlusal variables as assessed from siblings with overt malocclusions. Am J Orthod Dentofacial Orthop 1993;104: 121-31.

31. Trenouth MJ, Davies PH, Johnson JS. A statistical comparison of three sets of normative data from which to derive standards for craniofacial measurement. Eur J Orthod 1985;7:193-200.

32. Alcalde RE, Jinno T, Pogrel MA, Matsumura T. Cephalometric norms in Japanese adults. J Oral Maxillofac Surg 1998; 56:129-34.

33. Pogrel MA. What are normal esthetic values? J Oral Maxillofac Surg 1991;49:963-9.

34. Ko SJ, Kim HS, Kim YJ. The influence of gender or culture on determining esthetic facial profile. Korean J Orthod 2001; 31:301-9. 